\title{
ESTUDOS SOBRE ÉTICA NAS ORGANIZAÇÕES
}

A Ética nas Organizações, ou Business Ethics (BE), como a denominam no âmbito acadêmico-empresarial em todo o mundo, parecia ter perdido o encanto, quando as consequências de sua falta voltaram a recordar sua importância. Aquilo que parecia óbvio mostrou ser mais intrincado do que se imaginava. A transversalidade da análise da Ética Empresarial, como proposta por alguns líderes, indica que o compromisso pode se reduzir mais a marketing e cumprimento de requisitos do que a vontade séria de disseminar valores. Autores de vários continentes contribuem para um novo olhar sobre o tema, sobretudo com a perspectiva de países emergentes. A professora Maria Cecilia Coutinho de Arruda, da FGV-EAESP, que possui experiência de mais de 20 anos na área, indica alguns livros que não podem deixar de ser lidos.

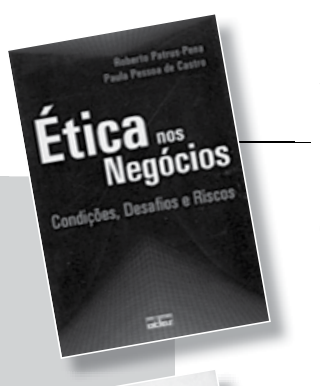

ÉTICA NOS NEGÓCIOS: Condições, desafios e riscos. Roberto Patrus-Pena e Paula Pessoa de Castro. São Paulo: Atlas, 2010. 205 p. 0 livro apresenta caminhos factíveis para reduzir a distância entre o discurso ético e a sua prática efetiva, evitando o risco de se utilizar a ética como maquiagem de ações que prejudicam trabalhadores, clientes, comunidade e outros stakeholders da empresa. Integra três dimensões da ética: a convicção, a responsabilidade e a virtude. Diferencia a empresa normal de uma empresa ética com base em pressupostos filosóficos. A metodologia empregada é moderna, agradável e bem-humorada.

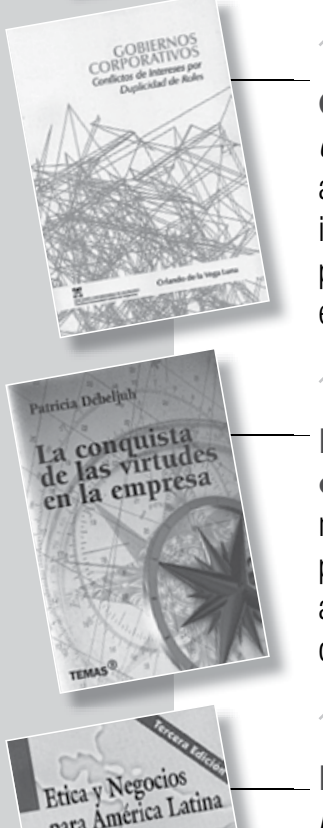

GOBIERNOS CORPORATIVOS: Conflitos de intereses por duplicidad de roles. Orlando de la Vega Luna. Valparaíso: Ediciones Universitarias de Valparaíso - PUCV, 2011. 255 p. Leis e policiamento ajudam a solucionar conflitos, mas a ética precisa ser vivida interiormente e com profundidade. 0 conflito de interesses por duplicidade de papéis aparece cada vez mais nos governos corporativos. 0 autor aponta a ética pessoal como caminho para solucioná-lo, por meio de um estudo sério e científico. Analisa o conceito, a natureza e os modelos de governo corporativo, os conflitos de interesses e a aplicação em casos chilenos.

LA CONQUISTA DE LAS VIRTUDES EN LA EMPRESA: El aporte de los códigos de ética. Patricia Debeljuh. Buenos Aires: Temas Grupo Editorial SRL, 2004. 303 p. Uma empresa com valores morais é um conjunto de pessoas comprometidas com a ética. A autora fala de virtudes como excelência das pessoas. Os códigos de ética indicam o que a empresa espera de cada colaborador. 0 livro analisa o objetivo, alcance, conteúdo e implicações do código de ética. Torná-lo eficaz significa alimentar uma cultura corporativa que favoreça a atuação ética e o desenvolvimento das virtudes. Em última instância, a excelência.

ÉTICA Y NEGOCIOS PARA AMÉRICA LATINA. 3. ed. Eduardo Schmidt. Lima: Universidad del Pacífico; OXY, 2000. 589 p. 0 livro é resultado de mais de 30 anos de pesquisa e docência na América Latina, principalmente no Peru. Responde às inquietações de economistas e administradores que desejam incorporar valores e princípios morais em sua tomada de decisões de modo realista. Apoiado na teoria do desenvolvimento humano de James W. Fowler, 0 autor analisa o profissional, a comunicação da verdade, o exercício dos direitos inerentes à propriedade privada e o preço justo.

FUNDAMENTOS DE ÉTICA DE EMPRESA: La perspectiva de un país en desarrollo.
Juan M. Elegido. México, DF: Ipade, 1998. 521 p. Com base em sua vivência e experiência na Lagos Business School, Nigéria, 0 autor foca o livro nas necessidades dos executivos e nas empresas que trabalham em países em desenvolvimento. Oferece um guia de ética empresarial, apresentando conceitos essenciais para a análise ética e princípios fundamentais da moralidade nos negócios. Aprofunda-se nas responsabilidades da empresa para com os stakeholders e para com a sociedade, bem como nas responsabilidades éticas e fiduciárias dos gerentes. 